\title{
From Warfare to Welfare Postwar Homelessness, Dislocation, and the Birth of the Welfare State in Europe: The Case of Berlin 1945-1949
}

\author{
Clara M. Oberle
}

$\mathrm{I}$ $\mathrm{n}$ past years, with state funding for public health and welfare undergoing much scrutiny, historians and public health policy makers alike have proposed to study the origins of what for years could be characterized as a European welfare consensus. Was there indeed any such conversion of approaches? And if so, what caused it? Among others, the Phoenix network, a coalition of scholars studying health care and medical policies over the course of Europe's history and in its present, called for an investigation of moments in European history when thinking on public health and welfare policies converged. ${ }^{1}$ This paper proposes that indeed there was a period in European history which generated something of a postwar convergence of approaches. The postwar period witnessed a remarkable consensus about the importance of public planning, spending, and state involvement in the health and welfare sector. By examining the case of Berlin as one immediate postwar city and situating it in the larger European context of the time, one can point to common motivations and actors involved. The root of this consensus was not any optimistic humanitarian ideology, nor even primarily a concern for public health or the spread of epidemics. Rather, it grew out of a shared setting, marked by physical destruction and political instability. As a result, profound concerns about governability and the legitimacy of any state came to the forefront. In the case of Berlin, this was aggravated furthermore by a fear of the return of National Socialism.

Following an introduction to the significance of the Berlin setting, the city's health and housing challenges will be situated in the postwar European context.

1 European Thematic Network on Health and Social Welfare Policy, Phoenix tn, "Health and Welfare: Diversity and Convergence in Policy and Practice," Athens 19-22 February 2009 University of Athens Building Kostis Palamas, Av. Akadimias, nr. 48 Athens. The author wishes to thank the Athens conference participants and the anonymous reviewers for their generous feedback. 
Image 1. Ruins, puddles, and exposure to elements in the fragmented city.

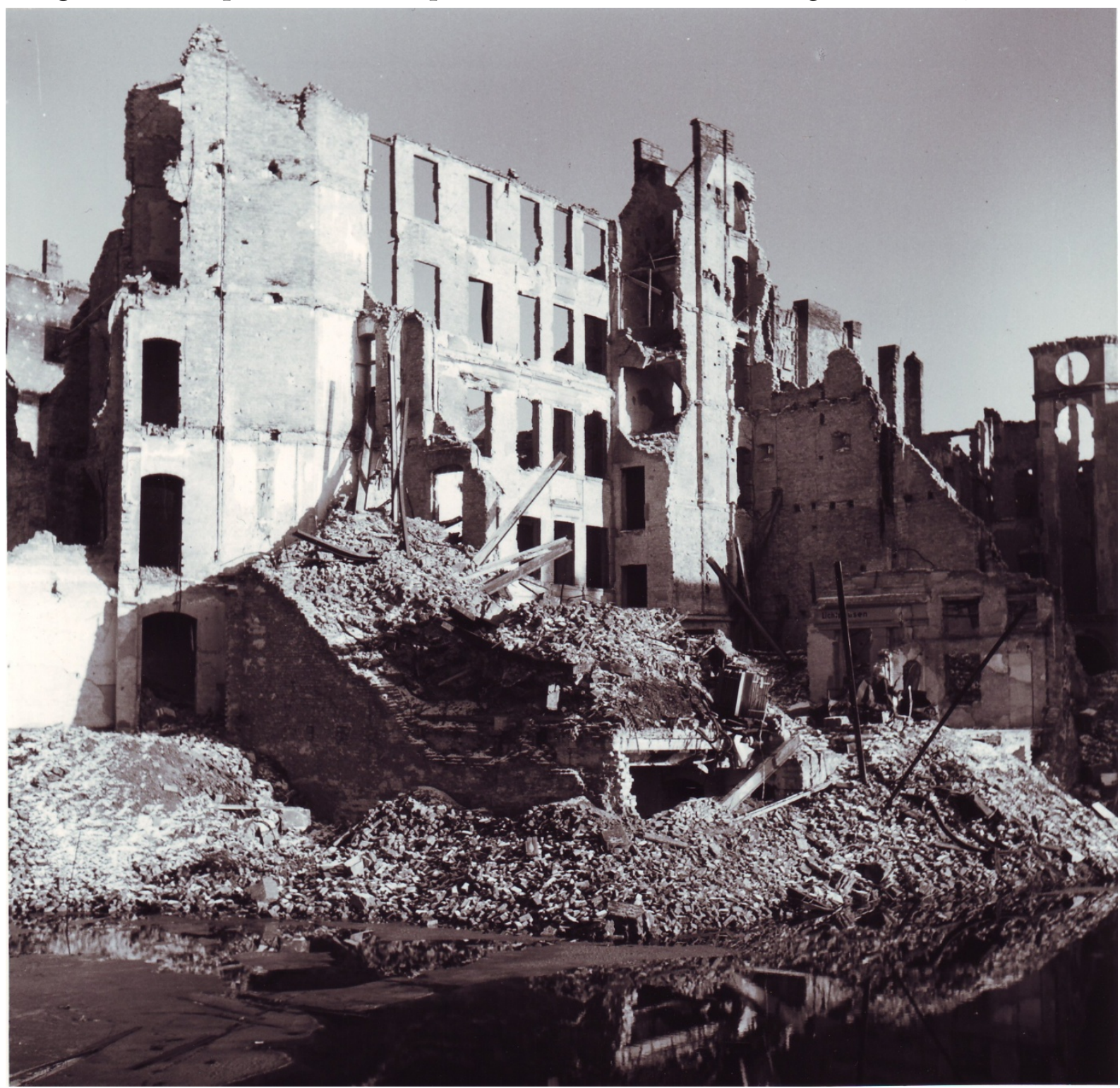

Courtesy of Landesarchiv Berlin.

Next, different factors leading to the emerging state interventionist consensus will be examined. The case of housing and concerns about contagion of infectious diseases, inter-Allied competition within the realm of public health, interventionist traditions and expectations, as well as the universalist international health discourses will be examined in particular.

The focus will be on commonalities and convergence of general underlying ideas rather than on specificities of different health policies. Of course, approaches did differ. The differences, for example, in policies vis-à-vis invalids or the various Allied collaborations with international organizations such as the Red Cross, the Office International d'Hygiène Publique, the World Health Organization, or the International Labour Organization, were pronounced. Likewise, the degree to which health and welfare policies at the municipal and district level related to or 
were inconsistent with statewide policy could differ significantly. The links between the levels of health and housing welfare administration were indeed manifold. Allied housing, health and medical officers stationed in Berlin operated on both the municipal and state level. They were thus closely involved in policy and procedure at the municipal and district level, e.g. overseeing the work of epidemic watch groups in their districts, monitoring and directing the resources of local hospitals, or gathering statistics on typhoid fever infection rates. At the level of the Allied Control Council, these very same officers debated national and state policy, including legislation. This paper focuses on the debate about state and governmental involvement in welfare. This, I argue, was a debate in which ideas converged. Practically all of Europe was concerned about the challenge of housing and providing for millions of displaced and distressed Europeans. This housing crisis, I suggest, was a founding moment in the history of health and welfare policy of Europe.

The sources for this study include scholarly studies about other European cities and countries; primary records including health and housing statistics; records of the International Red Cross and the United Nations Refugee Relief Organization; and a wealth of records from Allied and municipal offices concerned with housing and public health in Berlin 1945-1949, now held at Military Archives of Britain, the United States, Russia and France. Among the documents are weekly meeting minutes, decrees, law drafts, as well as internal and international correspondence with peers in Britain, Poland, Russia, Belgium and elsewhere by members of the occupying forces working in Departments of Health, Housing, and Public Safety in Berlin. In addition, correspondence between Berlin municipal welfare, health, and housing offices, their Allied counterparts, and individuals in France, Britain, Germany and elsewhere-now held at Landesarchiv Berlin, Staatsbibliothek, and in several district archives—-have been examined.

Why Berlin? The case allows for an international study of the approaches to the health and housing crises. Berlin was occupied by four different military and occupation governments in the immediate postwar period. The Soviets had arrived first, in March 1945, to be joined that summer by British, US and French forces. Allies and Germans alike brought elements of the welfare and public health discourses in their native countries to the discussions. In addition, the documents suggest that the actors were keenly aware that the health and housing problems they were addressing were not unique to Berlin. They repeatedly observed the commonality of the problem and thus they present the possibility to study an international debate. The Allies themselves agreed upon the necessity of international cooperation and the exchange of ideas about these common problems. One resulting example of cooperation was an institution called the International Committee on Building and Housing. Established in the fall of 1945, its members met weekly in Berlin under alternating Allied chairmanship. Many of the meetings included 
Germans as well as other European visitors. Its professed goal was the study of the common housing crisis, resulting public health concerns, and possible solutions. ${ }^{2}$ Its founding members noted that not just Berlin or German cities, but cities across Europe were facing common challenges of housing and providing for the health and well-being of their inhabitants. ${ }^{3}$ The committee did not simply invoke the example of Berlin, London or Paris; Amsterdam, Warsaw, Leningrad and other cities were just as present in the debates, again for sharing similar problems. As will be shown, numerous other examples of the awareness of the Pan-European nature of the problem can be invoked, from Surgeon Generals' communications and international relief organization to the public press of the day.

Indeed, the housing crisis was one of the common problems in immediate postwar Europe. Wars tend to unsettle and shift populations, and create homelessness. But this war initiated by Nazi Germany, subsequent occupations, war tactics, and war-related scarcity of resources for regular construction and repairs - even in countries less affected by bombings - unsettled so much more than the wars before. The subsequent result: millions of Europeans were homeless. Countless popular publications on the problem of housing were published in the middle and late 1940s. Whether one looks at specialized publications of the time, such as the United Nations Refugee Relief organization's "Europe's Homeless Millions," communications from Surgeon Generals of various European countries or military occupations, or even any popular newspaper of the latter half of the 1940s, the discourse included a large public. ${ }^{4}$ While the attention to destruction and rubble may have created an image of total destruction of European cities rather than partial loss of dwelling spaces, the housing crisis was indeed acute. Problems as they appeared in Berlin were mirrored across Germany. In Germany's larger cities of 100,000 inhabitants or more, on average 40 percent of housing was destroyed. All in all, roughly 7 million persons lost their homes. ${ }^{5}$ The housing and health problems were prominent across Europe. In France, for example, where the housing crisis has been studied by historians Danièle Voldman, Frédérique Boucher and Olivier Ratouis,

2 Akademie der Künste, Archiv für Baukunst [AKAB], Scharoun Nachlaß, Sch-01, Internationales Kommittee für Bau- und Wohnungswesen, Oct. 1945.

3 Ibid.

4 For example Fred K. Koehler, "Europe's Homeless Millions," Headline Series n. 54 (Nov.-Dec. 1945), and Janet Flanner in Time Magazine, Margaret Bourke-White in Life, Henry Ries for the New York Times. For further literature, see Alice Förster and Birgit Beck, "Posttraumatic Stress Disorder and World War II," in Richard Bessel and Dirk Schumann, eds., Life After Death: Approaches to a Cultural and Social History of Europe During the 1940s and 1950s (Cambridge, 2003), 28-30.

5 Steven Brakman, Harry Garretsen, and Mark Schramm, "The strategic bombing of German cities during World War II and its impact on city growth," Journal of Economic Geography v. 4 (2004), 201-218; F. Kästner, Statistisches Jahrbuch Deutscher Gemeinden 37 (1949), 361391. 
there was severe damage. Estimates point to 20 percent of French housing stock affected, resulting in several million homeless. ${ }^{6}$ Italy had lost roughly one million homes. ${ }^{7}$ In Britain and the Soviet Union, the housing shortages were even higher than in Berlin, as many contemporaries were keenly aware. ${ }^{8}$ And Poland, for example, had lost 45 percent of its urban housing stock, with some cities in Western Poland and the city of Warsaw suffering as much as 80 percent loss of housing.' Despite massive destruction, evacuees, displaced persons, refugees and others were flocking to these cities. In brief, most countries across Eastern, Western and Central Europe emerged from the war with the two-fold reality of population influx and destruction of dwellings. ${ }^{10}$ And in every case, the severe housing crisis affected urban centers disproportionately. The scholarly literature to date has noticed the loss of housing, but it has mainly been interested in reconstruction and building debates. As it turns out though, reconstruction was not an option in the late 1940s due to a lack of funds and raw materials, nor was it the most immediate concern.

The loss of housing of course did not only have architectural implications. More importantly, it was central to public safety, public health and welfare debates. And it may have led Europeans, including the European middle class and persons not generally thought of as championing state involvement, to embrace the idea of redi-

6 Danièle Voldman, La reconstruction des villes françaises de 1940 à 1954. Histoire d'une politique (Paris, 1997); Frédérique Boucher and Danièle Pauly, L'architecture de la reconstruction en france 1945 - 1953 (Paris, 1982); Bulletin des commissions départementales de la reconstruction $\mathrm{v}$. 4 (1946), 6-8.

7 Paul F. Wendt, "Post World-War II Housing Policies in Italy," Land Economics, v. 38, n. 2 (May 1962), 113-133. On Milan, see Achille Rastelli, "I bombardimenti aeri nella seconda guerra mondiale Milano e provincia," Italia Contemoranea, v. 195 (June 1994), 309 - 342. On Rome, see e.g. Cesare de Simone, Venti angeli sopra Roma: I bombardimenti aeri sulla Città Eterna 19 luglio e 13 agosto 1943 (Milan, 1993).

8 Potsdam Conference Protocol of the Proceedings, Art. 17, cited in Senate Committee on Foreign Relations and the Staff of the Committee and the Department of State, eds., A Decade of American Foreign Policy: Basic Documents, 1941-1949, (Washington, 1950). See also Sidney Bertheim, "Housing in France," in Land Economics, v. 24, n. 1 (Feb. 1948), 49-62; Frédérique Boucher, "Arbiter vaille que vaille, se loger coûte que coûte," in Danièle Voldman, ed., Images, Discours et Enjeux de la Reconstruction des villes françaises après 1945, Cahiers de l'Institut d'histoire du temps présent, n. 5 (Paris, 1987), 157; Nicole Rudolph, At Home in Postwar France: The Design and Construction of Domestic Space, 1945-1975 (New York: 2005)

9 Glowny Urzad Staystyczny Polskiej Rzeczypospolitej Ludowej, ed., Tablice Statistyczne 1953-1954, (Warsaw, 1956), 381-387; Gregor Thum, Die Fremde Stadt: Breslau 1945 (Berlin, 2003); Norman Davies, God's Playground: A History of Poland (Oxford, 2005); Philip Ther, Deutsche und polnische Vertriebene: Gesellschaft und Vertriebenenpolitik in der SBZ/DDR und in Polen, 1945-1956 (Göttingen, 1998). On statistics, see especially Katherine Lebow, Nowa Huta, 1949-1957: Stalinism and the transformation of everyday life in Poland's "first sociality city" (New York, 2002), 25.

10 Tony Judt, Postwar: A History of Europe Since 1945 (New York, 2005), ch. 1; Mark Mazower, "Displacement and Social Crisis," in Dark Continent: Europe's Twentieth Century (New York, 1998), $214 \mathrm{ff.}$. 
stribution of resources and housing. Moreover, the Berlin case shows that in not only health officials and medical experts from the district, municipal and national levels were concerned with health and housing. Allied political officers, police, military, and architectural experts were just as much concerned. They agreed that not just the general health was at stake. Finally, as will be shown, they would concur that a concerted effort was necessary to address a number of pressing concerns.

But what were the primary motivations for Allied actors to be involved with health and housing questions? One British Military observer in Germany put it into words typical of the military records describing the Berlin setting and the health and housing concerns of the Allies. He observed in October 1946: "The loss of housing accommodation as a result of war and the influx of refugees has created a housing situation - which is grave and probably unprecedented in history. Everything that can be done must be done and done quickly." And he continued, warning that lest there be rapid improvement of the situation, "the living conditions ... coupled with ... a harsh winter may bring in their train not just death, [and] disease, but also serious discontent, and even ... popular unrest." ${ }^{12}$ The letter, sent to the British High Command and fellow Allies, is marked "urgent."

These were the main concerns then: First, the fear of disease and the outbreak of epidemics. Second, the fear of subsequent discontent and unrest and thus, ultimately, the question of governability.

Allied concerns about the spread of illness and the outbreak of epidemics had gained in urgency over time. Not all were initially alarmist, yet in the most moderate health reports of the summer of 1945, housing and fears about health already featured prominently. Compared to many other European cities, Berlin and its residents at first seemed fairly healthy to members of the Allied Housing and Public Health department. This would not necessarily remain so, medical observers noted early on. Thus, upon surveying the city in June-July 1945, one public health report of the US Military Government in Germany instructed the US Surgeon General that "destruction ... ha[d] led to inadequate housing and overcrowding which [,] if coupled with inadequate heating facilities and soap [,] [might] result in lousiness and other unhygienic conditions during the winter." ${ }^{13}$ Still, in some of the early reports, dangers were described as potential dangers, and seasonal ones at that. The earliest American reports were particularly positive, noting, for example, that under

11 Public Records Office [PRO], Foreign Office Files [FO] 1012/516, Letter on "The German Housing Situation in the British Zone," 15 Oct. 1946, p. 1.

12 Ibid.

1312 July, 1945, National Archives and Record Administration [NARA], OMGUS RG 260, AG 720, "U.S. Army Plans for German Public Health under the Allied Control Council: A Report to the Surgeon General, US Army, of Observations Made from 6 June to 12 July, 1945" by Brig. Gen. James S. Simmons, USA Chief, Preventive Medicine, SGO, and Col. Thomas B. Turner, M. C., Director, Civil Public Health Division, SGO, page 6. 
the given conditions "the general health of German civilians" was "surprisingly good." ${ }^{14}$ This would change quickly.

Health concerns grew with increasing in situ knowledge of the availability of medical services, of the general public health and the increased infection rates of contagious diseases, and of the city's altered topography and infrastructure. Moreover, from late July on, the Allies and Berlin municipal offices collected detailed health statistics and infection rate reports every week from every Berlin administrative district and hospital which allowed them to identify areas of primary concern. ${ }^{15}$ Allied and municipal epidemic investigations in Berlin, as in Potsdam, may have also relied on neighborhood-based volunteer sanitary helpers and so-called Seuchenwarte. They had deployed the latter systematically to inspect all streets. The sanitary wardens also had to "visit all apartments on a daily basis" in a given neighborhood and report on any seemingly ill persons. ${ }^{16}$ Their reports only drove home the point to housing officials that something had to be done quickly in light of the "threatening ... situation." ${ }^{17}$ In addition, the Allies could rely on their own extensive health, hospital and housing surveys, conducted street by street, block by block, in the autumn of 1945. In these surveys they noted the availability of services, the health of the residents, as well as the crowd index, i.e. the number of persons living in one room. ${ }^{18}$ Finally, also the increased exchange of information across occupation zones helped show the extent of the health crisis.

Based on the evidence gathered in 1945 and early 1946, the Allies considered Berlin to be headed into a health catastrophe. Like most European cities affected by the war, the spread of disease threatened to take on epidemic, if not pandemic, dimensions. By the end of 1945, Berliners were ailed by typhoid fever, typhus, dysentery, diphtheria, influenza, cholera and tuberculosis, and some of these illnesses were spreading very rapidly. ${ }^{19}$ While it may not be unusual to see these in a population of nearly three million, the rates at which they were spreading appeared disconcerting. For example, within just one month, between June and July 1945, the number of persons registered as infected with dysentery in the Russian Zone of

14 Ibid., page 5.

15 Archiv der Akademie der Künste, Abteilung Baukunst, Scharoun Nachlaß, Records Mag 3/2 to $3 / 5$.

16 Landesarchiv Belin [LAB] C Rep 309, A 5018, Seuchen, Re: Fleckfieberbekämpfung, 6 Feb. 1946.

17 Ibid.

18 PRO FO 1051/803. Major Nuttall Report, "Notes on Visits to Various Premises in Berlin on 10. Sep. 1945,” pp. 1-2.

19 National Archives and Records Administration [NARA] OMGUS RG 260, AG 720, Department of Public Health Berlin, 12 July 1945. Andreas Dinter, Berlin in Trümmern. Ernährungslage und medizinische Versorgung der Bevölkerung Berlins nach dem II. Weltkrieg and Seuchenalarm in Berlin. Seuchengeschehen und Seuchenbekämpfung in Berlin nach dem II. Weltkrieg, Geschichte(n) der Medizin Series, v. 1-2 (Berlin,1999). 
Berlin doubled from 1,100 cases to 2,380. ${ }^{20}$ By September 1945, even American officials noted that the local population was not that healthy after all. Furthermore, medical observers worried that Allied and Berlin medical provisions, even if combined, would still be marked by pronounced shortages in vaccines, penicillin, equipment and personnel, and would not suffice to quell an outbreak of epidemics. ${ }^{21}$ The overall health of Berlin residents, like that of other European city dwellers, seemed to be taking a downward turn. ${ }^{22}$

Why become engaged, though? Allied officials in Berlin seldomly invoked humanitarian reasons for improving the health of local populations. Germans, they reminded themselves, had brought this calamity upon themselves. ${ }^{23}$ Debates in a variety of committees concerned with funding showed the prominent reasoning that since the Nazi Regime had so aggressively pursued war in the name of the wellbeing of the Aryan volk while bringing about immense suffering on the side of its victims, it was now only fair for Germans to suffer, even physically. Certainly, German standards of living were not to exceed those of other European countries. ${ }^{24}$ According to this vein of debate, if Allied resources were to be dispersed in Germany at all, they were to be administered only to those in most dire need, i.e. the ill and homeless. ${ }^{25}$ And even here, if humanitarian reasons were invoked, they concerned mostly children. ${ }^{26}$

A more prominent motivation for engaging in public health planning was the fear of contagion that would transgress class, political and geographical boundaries. Such concerns mirrored those expressed by governments and public health specialists of earlier centuries through to their contemporaries. ${ }^{27}$ Furthermore, "modern transportation" itself, as U.S. President Harry Truman had reminded the future World Health Organization, had made it "impossible for a nation to protect itself

20 NARA OMGUS RG 260, AG 720, Department of Public Health Berlin, 12 July 1945,

21 Ibid., Dec. 1945, Jan. 1946.

22 In Poland, infant mortality rates by war's end were twenty times, tuberculosis infection rates in 1947 ten times that of US Americans. See Katherine Lebow, Nowa Huta, 25.

23 Archives de l'Occupation Française en Allemagne et en Autriche (Colmar) [CArch], Série: Groupe Français du Conseil de Contrôle [1945-1948] GFCC, Caisse No: 3272, Carton No: P30, Allied Control Council, Housing and Building Committee, 53 Séance, tenue le 21 Octobre 1947.

24 Potsdam Conference Protocol of the Proceedings, Art. 17 (1945).

25 CArch GFCC, Caisse No: 3272, Carton No: P30, Allied Control Council, Housing and Building Committee, 53 Séance, tenue le 21 Octobre 1947.

26 Universities Committee on Post-War International Problems, ed. Ralf Barton Perry, Final Report of the Work of the Committee 1942-1945, Section V, (Boston, 1945), 3.

27 See the rationale for boards of health established in 16th century Italian cities, the reforms advocated by Johann Peter Frank, Jeremy Bentham, Edwin Chadwick, or records of 19th century international conferences such as the International Sanitary Conference in Istanbul, 1866. 
against the introduction of disease by quarantine. ${ }^{28}$ Ill and healthy would mix. Though quarantining was still a prominent approach — at borders or points of transit such as train stations-governments and military occupations had realized the degree to which boundaries between countries, between their residents, between occupiers and occupied would be permeable. In the Berlin case, this meant the health of Berliners was directly linked to that of their occupiers. In consequence, it was in the interest of the health of the Allied own troops and employees themselves to push for policies that benefited the health of the general public. A cordon sanitaire between local populations and military occupiers is never possible. Allied units, in moves similar to that of Berlin upper classes in the course of industrialization, relocated from the inner city neighborhoods to the outer districts, for example to Dahlem, Karlshorst, Reinickendorf, and Spandau, in order to get away from the unhealthy and unsanitary inner city. ${ }^{29}$ However, there was no way to create the "sanitary border" which Allied health professionals had at first called for. ${ }^{30}$ The contacts were simply too many.

Where and how could illnesses spread from occupier to occupied? The stories of rapes and acts of intimate fraternization-often taking place in Berlin homes and basements- have been well documented..$^{31}$ Not only the Red Army command but also western Allied officials acknowledged the fact that physical interactions between German civilians and occupation personnel would inevitably take place, despite fraternization bans. ${ }^{32}$ Noting that in German cities "the social chaos among civilians" had made "unusually difficult ... the adjustment of the relationships between soldiers and civilians," one secret American health report from late May 1945, addressed to the US Surgeon General, advised that is was "not practicable to take action which [would] materially reduce contact between soldiers and prosti-

28 Harry Truman, "Letter of Welcome to the Inaugural Meeting on June 22, 1946," cited in United Nations, Chronicle of the World Health Organization, v. 1, n. 1 (1947), 8.

29 William Durie, Friedrich Jeschonnek, Dieter Riedel, et. al., Alliierte in Berlin: 19451994: Ein Handbuch zur Geschichte der militärischen Präsenz der Westmächte (Berlin, 2002); Norman Naimark, Russians in Germany: A History of the Soviet Zone of Occupation, 1945-1949 (Cambridge, 1995); PRO FO 1051/150 Requisitioning, Dec. 1946 Report; PRO FO 1012/80 "Housing Allocation in Charlottenburg for Military Persons" [n.d.]; PRO FO 1051/150 Requisitioning 1945-1948, Lt. Col. E.D. Bevan to Military HQ, Berlin 28 Aug. 1946; NARA, RG 260 OMGUS Still Pictures, MGG 260-274-4.

30 NARA RG 260 OMGUS 1945-46 AG 72, 21 Feb 46, signed McNarney.

31 For an overview of this historiography, see Karen Hagemann and Stefanie SchullerSpringorum, Homelfront: the military, war, and gender in twentieth-century Germany (Oxford/New York, 2002). See also contributions to the War and Rape issue of October, entitled "Liberators take Liberties," i.a. Atina Grossmann, "A Question of Silence: The Rape of German Women by Occupation Soldiers," and Andreas Huyssen et. al, "Further Thoughts on Helke Sander's Project" October, v. 72, (Spring 1995).

32 For an excellent study of US-German fraternization, see especially Petra Goedde, GIs and Germans: Culture, Gender and Foreign Relations (New Haven, 2003). 
tutes. ${ }^{33}$ In addition to the spread of venereal diseases like syphilis and gonorrhea, such intimate contact could lead to a spread of typhoid fever, influenza, dysentery, diphtheria and other contagious illnesses which occurred with increasing frequency among military personnel stationed in Berlin. ${ }^{34}$

The Allies had to fear contagion not merely as a result of intimate physical interactions. There were many other areas of contact. Allied housing officers could, for example, catch infections on their inspection tours, as happened to Major Nuttall who contracted dysentery. ${ }^{35}$ Berliners and Allies shared the same water, sometimes the same food. They frequented the same train stations and the same streets. And sometimes they even lived under the same roof and shared the same sanitary equipment. ${ }^{36}$ Furthermore, German employees worked for military administrations of all four Allies. In particular the German food handlers, cooks, and kitchen help for the occupiers, both in the garrisons and the villas of the Highest Command, could and did spread disease. Thus, the "outbreak of disease ... among civilians" could "sufficiently endanger troops or seriously impede military operations." ${ }^{37}$ Another member of the military government in Berlin had to remind his superior abroad that the call for funding to improve Berlin's hygienic infrastructure did not primarily stem from empathy with Berliners. Rather, he noted: "The problem of sanitation in Berlin is of paramount importance for all of us who live here." ${ }^{18}$ The records point to a Berlin-based conclusion that reducing the "reservoir [of] infection... among German civilians" would best ensure the health of the occupying forces. $^{39}$

Reducing this reservoir of infection took many forms and involved individual efforts as well as those of various branches of Allied and municipal government. Over time, a consensus emerged which held that uncoordinated action would not suffice in light of the serious health crisis. Instead, unified planning and the apparatus of the state would be necessary to address the problem.

Initially, though, measures for reducing the threat of the spread of epidemics were taken sector by sector. Reducing the reservoir of disease at first literally related to reservoirs and water supplies. Sanitizing the cityscape physically, removing rubble, shells, corpses of men and animals alike, repairing sewage pipes, and draining

33 NARA RG 260 OMGUS 1945-46 AG 720, 16 May 45 Health Report.

34 NARA RG 260 OMGUS 1945-46 AG 720, n.d. summer 1945, n.d. Jan. 1945, 26 Feb. 1946, n.d. Feb. 1946.

35 PRO FO 1051/803 Letter from A.E. Joll to H.H. Nuttall, [n.d.].

36 PRO FO 1051/150 Requisitioning, Report of 15 Feb. 1947; PRO FO 1012/80 "Housing Allocation in Charlottenburg for Military Persons" [n.d.], and FO 1051/150 Requisitioning 1945-1948, Lt. Col. E.D. Bevan to Military HQ, Berlin 28 Aug. 1946.

37 NARA RG 260 OMGUS 1945-46 AG 720, OMGUS Report to Surgeon General, 6 Jun to 12 July 1945.

38 NARA RG 260 OMGUS AG 720, 19 Apr. 1946, Subject: Sanitation.

39 NARA RG 260 OMGUS 1945-46 AG 720, Jan. 1946 Report. 
cess-pools was one way in which Allies and Berliners went about addressing questions of hygiene and infrastructure. ${ }^{40}$ These efforts, often initiated at district levels, were uncoordinated.

Only upon the arrival of large groups of returning evacuees, refugees, and socalled displaced persons (DPs) did the Allied Control Commission create joint policies for Berlin. Despite common interests, these too only emerged with experience on the ground. As Berlin municipal police noted in July 1945, every day between 5000 and 6000 refugees and DPs arrived in Berlin's over-extended train stations, where homeless Berliners were already residing. ${ }^{41}$ By the winter months 1945-1946, the records speak of 500,000 refugees a month traversing Berlin. ${ }^{42}$ Allied and railroad personnel were not the only ones who regarded DPs and refugees as a menace. Berliners shared the view of Allied and municipal administrators which regarded such people as a "hearth of disease," a "flood," "wave," or "stream" of menacing proportions threatening the health of the community. ${ }^{43}$ A police order of the Berlin district of Friedrichshain simply read: "Travelers passing through Berlin who touch [sic] our district ... must leave ... immediately." ${ }^{44}$ Contagion, again, was to be prevented. Very likely, these refugees, DPs, and former camp inmates were indeed of poor health. Once in proximity to others, Allies and Berliners feared, they might spread their illness or the host of their illness quickly. However, at first policies were at the level of each occupation zone. Soviet decrees from October 19, 1945 demanded that 36,000 German railroaders be immunized against typhoid fever, 11,500 in the Soviet Zone of Occupation alone. But medicine and disinfectants were constantly in short supply in Berlin, and not all could be immunized. ${ }^{45}$ Meanwhile, delousing stations, which refugees and returnees were required to visit, or soap and boiling water provided at

40 LAB C Rep 309 A 5021, "Betr: Der Grundwasserstand as Spiegelbild der Entwicklung und Wirtschaftslage Berlins” letter by Reichsbahn Direktor Kreikemeyer to engineer Dr. I. Denner regarding water and broken pipes, 11 Nov. 1947; LAB, C Rep 303-09, no. 11, "Betr: Bekämpfung von Stechmücken" and "Betr: Entmückungstrupps," 13 May 1946.

41 Jan Foitzik, ed., Inventar der Befehle des Obersten Chefs der Sowjetischen Militäradministration in Deutschland (SMAD) 1945-1949, Series of Institut für Zeitgeschichte (Munich, 1995), p. 16 of "Befehl No. 15," Berlin, 27 Jul. 1945.

42 Reinhard Rürup, ed., Berlin 1945: Eine Dokumentation (Berlin, 1995), 124.

43 Befehle des Obersten Chefs der Sowjetischen Miltärverwaltung in Deutschland und amtliche Bekanntmachungen des Stabes der Sowjetischen Militärverwaltung in Deutschland, Sammelheft 1, 1945 (Berlin, 1946), 16, 39-40 and Norbert Podewin, ed., Ausgangspunkt Chaos: Berlin im Mai und Juni 1945: 100 Dokumente vom Leben rund um den Schlesischen Bahnhof (Berlin, 1995),16.

44 Ibid.

45 LAB C Rep 309 A 1910, letter Reichsbahn Direktion Berlin to Reichsbahnsozialamt, 31 Oct. 1945. 
the Bahnhofsmission shack, only provided limited protection. ${ }^{46}$ In July 1945, the first unsettled persons to arrive were therefore kindly advised to leave Berlin unless they were already in the care of Berlin relatives. ${ }^{47}$ This strategy proved ineffective with the arrival of ever more refugees. Soon, the tone changed. Those in positions of power concluded that the simplest way to protect the health of the community was to quarantine and ban refugees altogether, and thus limit the spread of disease. By 1946, the Allies agreed on a common policy: any refugee traveling "wildly" [wildreisend] and not as part of a group under Allied supervision, was to be captured, taken to the station master, quarantined, delivered to Allied authorities, and forced to leave the city within 24 hours. $^{48}$ Organized mass transports of refugees and DPs which entered the city were also to be held in quarantine, watched night and day by military police and local auxiliary forces. Eventually, in every sector, they were to leave the city within less than a day, refugees and DPs being carried to camps set up outside the city which would provide medical care. ${ }^{49}$

What, however, was to be done with residents within the city and the continuous fear and reality of spreading disease? Military officials and their health officers throughout 1945 to 1948 lamented a shortage of immunizations for German civilians and their own populations; in this area, the means were limited. ${ }^{50}$

The best possible protection, Allies and Berliners came to agree, was to remove the ill, homeless Berliners from the streets and send them to hospitals. Yet the responses here showed different strategies and signs of conflict amongst the Allies. Upon their arrival, hospitals already had been filled beyond capacity, so often infected patients were turned away to stay in already crowded apartments where the tenants or owners would be made to share their dwelling space. Patients known to be contagious lay in mixed-use buildings which served as general hospital, school and housing facilities all at once - or they had simply been sent home. ${ }^{51}$ At home though, in crowded living conditions, the sick sharing rooms with healthy could spread their illnesses further.

46 LAB C Rep 309 A 5018, Re: Flüchtlingsangelegenheiten und Seuchen, letter entitled "Fleckfieberbekämpfung," Provinzialverwaltung Brandenburg, 6 Feb. 1946.

47 LAB C Rep 309 A 5018, Re: Flüchtlingsangelegenheiten und Seuchen, 9 Jul. 1945.

48 LAB C Rep 309 A 5018, Re: Flüchtlingsangelegenheiten und Seuchen, "Betr: Betreuung der aus dem Osten kommenden Umsiedler," signed RB Direktor Bäuerle, 26 Mar. 1946. These instructions were sent to all border and transit railway stations, including to Berlin.

49 LAB C Rep 309 A 5018, Re: Flüchtlingsangelegenheiten und Seuchen, 25 Jan. 1946, 29 Jan. 1946. On health care policies in DP camps, see Atina Grossmann, Jews, Germans, and Allies: Close Encounters in Occupied Germany (Princeton, 2007).

50 NARA OMGUS RG 260, AG 720, OMG Berlin to SGO, Re: Medical Requirements, Dec. 1945, 13 Jan. 1946.

51 AKAB, Scharoun-Nachlass, Mag 3/5, I Reports to Allied Kommandatura by Prof. Hassenpflug and Pfluger, Berlin Municipal Office of Health [Gesundheitswesen] to Allied Commandatura, Re: Leichenhallen. 
Allied observers and local public health experts deemed the proximity of Allies, city employees, infectious patients, school children, and residents "not advantageous in the long run." ${ }^{52}$ Indeed, Berlin health officials frequently compared different responses and health conditions. They thus provide examples of concrete conflicts arising from the various Allied strategies and of tensions between municipal health planners and their Allied counterparts. For example, the close proximity of ill and healthy in Zehlendorf (US Zone) and Lichtenberg (Soviet Zone) left Berlin municipal health personnel outright appalled. ${ }^{53}$ In one case, observers noted more than 500 tuberculosis patients were made to share space with students and nurses residing in a school building. ${ }^{54}$ As municipal health evaluator Hassenpflug noted, hospital beds for the sick and elderly, as well as overall medical provisions for Berliners were particularly poor in the northeast and east, i.e. the Soviet Sector. The Soviet-occupied districts of Kaulsdorf, Marzahn, Wuhlgarten, and Lichtenberg were singled out. ${ }^{55}$ Here, former military barracks which had been turned into hospitals during National Socialist governance were now being used to house healthy Soviet troops rather than the ill and contagious Berliners. Indeed, compared to other Allies, the Soviets required more potential housing or hospital space as they sought to isolate their personnel more than the Western Allies did. Not only in the realm of health, but possibly also in political ideology, contagion concerns may have been at the forefront of Soviet policy. Noting the overall lack of joint Allied initiative, the lack of resources in the Soviet areas, and the inconsistent measures even among each Allied group, Berlin observers called increasingly for a concerted effort and long-term planning in light of the numerous "inappropriate improvisations." Having likened many of the Allied health policies to "Nonsens" [sic], they pushed for greater Berlin municipal participation in health policy and for grand planning. ${ }^{56}$

The approach of favoring state and municipal involvement in providing sufficient housing and hospital space and the propagation of the isolation of patients already had a long tradition in Berlin. In his March 1882 lectures at the HygieneInstitut of Berlin's Friedrich-Wilhelms Universität, Robert Koch had demanded measures to prevent the spread of infections. They required not only the isolation of patients with open tuberculosis, but most notably, state- and municipality-organized initiatives to improve unfavorable housing conditions. Enough ventilation

52 AKAB, Scharoun-Nachlass, Mag 3/5, I, Reports to Allied Kommandatura on hospital capacity and overcrowding by Prof. Hassenpflug and Pfluger, Berlin Municipal Office of Health to Allied Commandatura, Re: Krankenhaus Kaulsdorf, dated 12 Jul. 1946 and 27 Sep. 1946.

53 AKAB, Scharoun-Nachlass, Mag 3/5, I, Reports to Allied Kommandatura by Prof. Hassenpflug and Pfluger, Berlin Municipal Office of Health to Allied Commandatura, Re: Zinnowaldschule in Zehlendorf, 14 Nov. 1946.

54 Ibid., Gutachten, 14 Nov. 1946.

55 Ibid.

56 Ibid. 
and space would be key. ${ }^{57}$ Ultimately, patients and healthy would be separated, once enough hospital space became available.

Yet at which level was health policy to operate? Should there be centralized plans for all of Germany? Should policy operate at the municipal level in a centralized way? At the district level in a decentralized way? The suggestions were many, and the debate about the level at which health care was to be administered continued, not least in response to Nazi policies which had centralized municipal health and welfare while creating competing Reich and NS party agencies to execute them. ${ }^{58}$ Suffice it to note that district and municipal health and housing administrators alike advocated the centralized, comprehensive "hygienische Durchplanung Berlins," with plans coming from the municipality. ${ }^{59}$

Meanwhile, according to these same municipal observers, the funding for comprehensive measures should come from both Berlin municipality as well as from the state, in this case the Allied Kommandatura. ${ }^{60}$ Initiatives by private insurance companies for repairing hospitals and privately operated hospitals were apparently accepted, though not favored, by Allies or Berlin municipal supervisors. They regarded the private businesses as operating out of business interest, not public health interest. Indeed, more than once, private villas had received building materials and been reconstructed under the guise of operating as a private clinic, never to actually provide the promised services. ${ }^{61}$ The same municipal observers meanwhile lauded the Allied Kommandants' joint provision of 4 million Reichsmark in emergency funds to the Magistrate of Berlin for 10,000 extra hospitals beds, as the right approach. ${ }^{62}$

Such calls were indeed eventually met with concerted Allied action by late 1946 . Consequently, the Allies jointly agreed to additional funding for the construction of hospitals, for hospital salaries, as well as the provision of building materials, all in response to the urgently perceived danger of epidemics. ${ }^{63}$

57 Herbert Landmann, "In Berlin begann der Kampf gegen die Tuberkulose," Berlinische Monatsschrift, v. 12 (1998), 12-13, 17.

58 See especially Christoph Sachße and Florian Tennstedt, Der Wohlfahrtsstaat im Nationalsozialismus (Stuttgart/Berlin, 1992); Alfons Labisch and Florian Tennstedt, "Gesundheitsamt oder Amt für Volksgesundheit? Zur Entwicklung des öffentlichen Gesundheitsdienstes seit 1933" in Medizin und Gesundheitspolitik in der NS-Zeit, ed. Norbert Frei (Munich, 1991).

59 AKAB, Scharoun-Nachlass, Mag 3/5, I, Reports to Allied Kommandatura by Prof. Hassenpflug and Pfluger, Berlin Municipal Office of Health to Allied Commandatura, Gutachten, 16 Nov. 1946.

60 Ibid.

61 Ibid.

62 Ibid., "Kommandanten stellen 4 Millionen Reichsmark"

63 AKAB, Scharoun-Nachlass, Mag 3/5, I, Reports to Allied Kommandatura by Prof. Hassenpflug and Pfluger, Berlin Municipal Office of Health to Allied Commandatura, 14 Nov. 1946 and Re: Seuchenbettenaktion, Dept. of Housing and Building Report to Allied Commandatura, 19 Feb. 1946, 31 May 1946. 
Before a concerted response of the type described above materialized in 1946, the different districts and Kommandaturas had taken individual measures against the spread of epidemics, in particular regarding overcrowding and the mixing of infected and healthy residents. The Soviets were the first to do so, both in terms of health infrastructure and actual projects. Per Soviet Military Administration Decree 17, a central health administration, Zentralverwaltung für Gesundheitswesen, had been set up in the Soviet occupation zone. ${ }^{64}$ While it differed significantly from NS racial hygiene goals and propagated an egalitarian approach as well as preventative medicine, it followed the NS path of expanding and centralizing the state-run public health system. ${ }^{65}$ Turning to specific interventions, the Red Army had also set up extra infectious disease hospital care in the district of Prenzlauer Berg in late spring 1945. Correspondence among different Allied health offices show that within days of the US and British arrival in Berlin, competition was prominent. Thus, Soviet health administrators urged American health officials to set up extra infectious disease centers in their central districts, e.g. in the populous district Neukölln which was especially short of infectious disease hospital beds. ${ }^{66}$ In addition, they pointed to poor housing structures and crowded living conditions in the West, which, in their opinion, worsened the health situation. ${ }^{67}$ On the other hand, health and welfare offices in the American-controlled districts of Berlin permitted and encouraged aid from outside agencies. These included not just churches and neighborhood charity organizations, but, for example, support from the Swedish Red Cross, the Swiss Red Cross, the International Red Cross, and eventually US health and humanitarian aid organizations which had been approved by CRALOG, the Council of Relief Agencies licensed to operate in Germany. ${ }^{68}$

The Allied material responses to specific housing problems - to broken windows, exposure to elements, or lack of ventilation-presents another example of the slow emergence of concerted state planning in the interest of public health. Destruction

64 Jan Foitzik, ed., Inventar der Befehle des Obersten Chefs der Sowjetischen Militäradministration.

65 Udo Schagen and Sabine Schleiermacher, "Gesundheitswesen und Sicherung bei Krankheit," in Bundesministerium für Arbeit und Sozialordnung/ Bundesarchiv, ed., Geschichte der Sozialpolitik in Deutschland, v 2: Die Zeit der Besatzungszonen 1945-1949 (Baden Baden, 2002); Ralf Ahrens, "Planwirtschaft, Prävention und Effizienz: Zur Wirtschaftsgeschichte des Gesundheitswesens in der Sowjetischen Besatzungszone und der frühen DDR," in Udo Schagen and Sabine Schleiermacher, eds., Sozialmedizin, Sozialhygiene, Public Health: Konzepte und Visionen zum Verhältnis von Medizin und Gesellschaft in historischer Perspektive, Series Berichte und Dokumente zur Zeitgeschichte 5, (Berlin, 2002) 42.

66 NARA OMGUS RG 260, AG 720, Department of Public Health Berlin, 12 Jul. 1945.

67 NARA OMGUS RG 260, AG 720 Report to Surgeon General, 6 Jun to 12 Jul. 1945.

68 NARA OMGUS RG 260/390/48/13/2/b209/16a, Report on the Activities of Social Welfare from July 1 - December 31, 1946. 
Image 2. Interior of Berlin apartment building, Berlin-Wedding, ca. 1946.

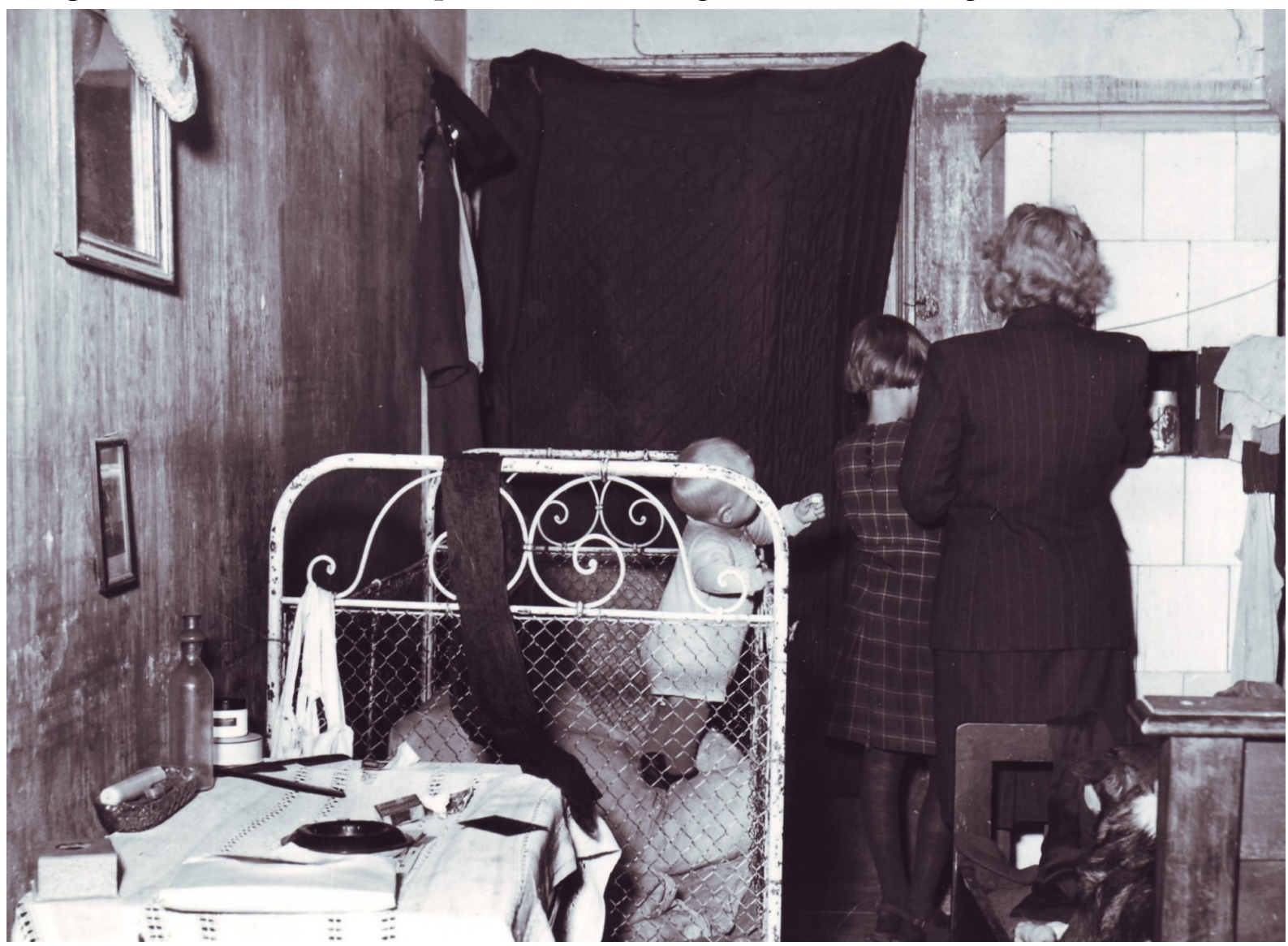

Courtesy of Landesarchiv Berlin.

of windows had led to residents being exposed to elements, with detrimental effects particularly during the winter months. Health officials had noted the rise in pneumonia and other acute respiratory diseases. ${ }^{69}$ As counter-measure, warming halls were set up for thousands of Berliners, initially by individual districts, later in a more coordinated manner. This followed a tradition of emergency relief already established by the district social services during the Third Reich and harkening back to the first Berlin warming hall of 1891. Also, by private residents' initiative, or in the Soviet and British cases, per Allied decree, windows had been covered by wool cloth, cardboard, wooden planks, or bricks, so as to make some rooms heatable. This however had limited the supply of fresh air and presented new health challenges, aggravated further by overcrowding. On their joint tours of Berlin dwellings, the members of the Allied Housing and Health Boards had noted numerous cases of serious overcrowding, with up to 15 persons residing in one room. ${ }^{70}$ Bricked up windows and dense settlement featured prominently in health and housing experts' discourses about the health of Berlin's residents in this early post-

69 NARA OMGUS RG 260 AG 720, 1945-46, Public Health, Berlin Report, Dec.1945, Jan. 1946, 19 Apr. 1946, 24 Apr. 1946.

70 PRO FO 1051/803. Housing Reports I, Housing Report, 28 Sep. 1945. 
war period. They were marked in particular by a concern for proper ventilation and minimum living space requirements per person. This dated back to older public health debates. Interwar Berlin and German architects had already called for space, air, light and sunshine in the interest of public health, as had the earlier Prussian housing legislation of $1907 .^{71}$ This legislation had made light and proper ventilation mandatory, and in turn, was based on nineteenth-century works on hygienics and housing such as Max von Pettenkofer's Über den Luftwechsel in Wohngebäuden. ${ }^{72}$ In this tradition then, and in light of frustrations over non-comprehensive solutions over different standards set for minimum standards of living, by March 1946 the Allied Control Council members agreed on a housing law for Germany which was to entitle every German to ample and appropriate, i.e. healthy, housing space. ${ }^{73}$ Therefore, when housing conditions were linked with health, and the call came for state involvement, this was part of a longer tradition. Despite this longer tradition of state involvement, the immediate postwar years were a period of particularly noteworthy convergence in regards to welfare and public health thinking. The postwar material setting and the urgent threat of spreading epidemics had made actors on all sides embrace concerted intervention.

Next to the specific material conditions and health crisis, a key reason for the postwar embrace of state intervention lay in the very weakness of the state. In Germany, as in most European countries, the immediate postwar period saw strong state apparatuses coupled with weak, tenuous governments. The provision of welfare came out of the very weakness of postwar governments. As British Miltary Governor for Germany Sholto Douglas had noted, "the living conditions ... coupled with ... a harsh winter" were likely to bring "not just death, [and] disease, but also serious discontent, and even ... popular unrest." ${ }^{74}$ State legitimacy and, ultimately, governability were the driving concern. In the case of Berlin, Allied offices of public safety, health, housing, and political affairs were very much involved. But no less important were the citizens of each state who expected their postwar state to take care of them and expressed this expectation. A state's failure to do so would lead to dwindling legitimacy.

In the case of Berlin during the early months of occupation, Allies were particularly sensitive to German public opinion. Contrary to most descriptions in the histories of Allied occupation, the representatives of the so-called "Great Powers" in 1945 felt all but secure. The frequently-referenced experience of World War I had

71 The last prewar international architectural exhibit in Berlin, 1932, had thus been aptly entitled "Sun, Light, and Housing for Everyone." See also Paul Wolff's film on Ernst May, Neues Wohnen in Frankfurt am Main (Frankfurr, 1928), and David Frisby on Martin Wagner, "The City Rationalized," in Cityscapes of Modernity: Critical Explorations (Cambridge, 2001), 270-302.

72 Max von Pettenkofer, Über den Luftwechsel in Wohngebäuden (Munich, 1858).

73 PRO FO1051/720. Housing Law 18.

74 Ibid. 
shown that having won a war did not automatically preclude future German aggression. The Allies were keenly aware of the challenge of pacifying Germans for the long term. In the earliest months of their governance in Germany, they spent much effort gauging popular opinion. Surveys conducted in Berlin and elsewhere, as well as popular opinion expressed in German media, showed great discontent on the part of Germans vis-à-vis the Allies. ${ }^{75}$ Berliners lamented their standard of living and saw Hitler's prediction fulfilled, i.e. that "the peace would be terrible," that they would suffer under some Allied yoke, that health and living conditions would be close to unbearable. ${ }^{76}$ Berliners did not greet the Allies as liberators in those early months, but as conquerors and enemies that had spread "terror." They still regarded the Allies' presence as "catastrophe" rather than liberation." Allied housing procedures, furthermore, were repeatedly appealed and questioned in legal settings. ${ }^{78}$ In a weak governance situation then, in which the Allied Control Council-the de jure government of Germany-lacked popular support, welfare policies which addressed health and housing concerns could be used to win over a skeptical and apprehensive population. Alternatively, policies the Germans considered insufficient, "nonsense," or detrimental would hinder such support.

Residents of immediate postwar Berlin, as elsewhere in Europe, approached their state's government with great expectations. The idea that a state was to provide for the wellbeing and, by extension, for the health of its citizens, rested on a longer tradition. At least since the Enlightenment, the strength of the European state had come to be identified with strength, resilience, and the well-being of its citizens. ${ }^{79}$ During the French Revolution, with the establishment of a Health Committee of the National Constituent Assembly, "health" had been proclaimed "a natural right." And thus, as historian Anne La Berge has noted, "if governments were instituted to protect natural rights, then public health was the duty of the state." ${ }^{\prime 0}$ By this logic, governments would lose legitimacy if they failed to protect those natural rights. These ideas had spread beyond France. Already a century prior to the

75 PRO FO 1051/803. Housing I, "Poor Rebuilding Prospects" [n.d.], Runge quoted by Head of Municipal Building authority and ibid., Ministry of Economic Warfare, confidential report, Press and Broadcast Unit, "Berlin's Housing Problem," 7 Jul. 1945.

76 See Deutsches Historisches Museum Exhibit, Alltagsleben 1945, "Geniesst den Krieg, denn der Friede wird schrecklich," attributed to Hitler and Goebbels. For Nazi predictions of the postwar order, see e.g. NSDAP, ed.., "Ohne Sieg kein Wiederaufbau," in Redner-Schnellinformation, v. 63, (September 1943).

77 Eike Wolgast, Die Wahrnehmung des Dritten Reiches in der unmittelbaren Nachkriegszeit 1945/46 (Heidelberg, 2001).

78 FO 1051/804, Housing Reports Berlin 1946-1949. Dec. 1946 Housing Report Berlin.

79 Thomas Osborne, "Of Health and Statecraft," in Alan Petersen and Robin Bunton, eds., Foucault, Health and Medicine (London, 1997), 173-188.

80 Ann F. La Berge, Mission and Method: The Early Nineteenth-Century French Public Health Movement (Cambridge,1992), 16. 
Allied and Berliner debates of the 1940s, at a time of similar political crisis, Rudolf Virchow had emphasized that "any reasonable state constitution" would have to note firmly "the right of the individual to a healthy [gesundheitsgemäße] existence." " The wellbeing of every citizen would have to be ensured by the state and its government. ${ }^{82}$ And as Jessica Reinisch has shown, this very Rudolf Virchow would become an icon for postwar Berlin medical officials. His calls for state and health reform were particularly hailed in the Soviet Zone. ${ }^{83}$ Lay persons may have likewise come to equate state legitimacy with health. During the early part of the twentieth century, both the institutions of the German state and the scientific community, including social hygienicists, doctors, and statisticians, had spent considerable effort in presenting national health statistics to general audiences. In popularized form, such as in the International Hygiene Ausstellung in Dresden in 1911 and 1930/31, as well as the Grosse Ausstellung zur Gesundheitspflege, Soziale Fürsorge und Leibesïbungen 1926 in Düsseldorf, the link between state and government legitimacy and collective strength or health of the nation, later volk, had been strongly emphasized. ${ }^{84}$

Most importantly, the experiences of the 1930s and 1940s had brought health and state legitimacy to the forefront. "It is a cruel paradox, but war, despite its immediate, catastrophic effects on human well-being, has played a major role in the evolution of the welfare state," historian Gregory Kasza has noted about the emergence of the Japanese welfare state. ${ }^{85}$ In Berlin, across Germany, and across Europe, the war is likely to have played this role. The Beveridge report and subsequent public health legislation in Britain would be unthinkable without the context of war which had at once empowered the interventionist state and strengthened the idea of the social contract. It encouraged popular demands vis-à-vis the state as caretaker. In France, likewise, the sacrifices made during the war had heightened popular

81 Rudolf Virchow, "Mittheilungen über die in Oberschlesien herrschende Typhus-Epidemie," Virchows Archiv für pathologische Anatomie und Physiologie und klinische Medicin n. 2 (1849), 317. Quoted by Heinz-Peter Schmiedebach, "Gesundheit und Prävention in Abhängigkeit vom Gesellschaftsbegriff im 19. Jahrhundert," in Sigrid Stöckl et al., Prävention im 20. Jahrhundert: Historische Grundlagen und aktuelle Entwicklungen in Deutschland (Weinheim, 2002) 27.

82 Rudolf Virchow, "Die öffentliche Gesundheitspflege," Die Medizinische Reform n. 1 (1848), 22.

83 Jessica Reinisch, “'Zurück zu unserem Virchow!' - Medizinische Karrieren, Nationalhelden und Geschichtsschreibung nach 1945," in Axel C. Hüntelmann, Johannes Vossen and Herwig Czech, eds., Gesundheit und Staat: Studien zur Geschichte der Gesundheitsämter in Deutschland, 1870-1950 (Husum, 2006) 255-271.

84 Sybilla Nikolow, "Statistische Bilder der Bevölkerung in den großen Hygienausstellungen als Wissensobjekte," in Rainer Mackensen and Jürgen Reulecke, ed., Das Konstrukt "Bevölkerung" vor, im und nach dem "Dritten Reich," (Wiesbaden, 2005), 476-477, 481-483.

85 Gregory J. Kasza, "War and Welfare Policy in Japan," Journal of Asian Studies, v. 61, n. 2 (May, 2002), 417. 
expectations for health care and welfare in the postwar period. ${ }^{86}$ State capacities to intervene, even after 1945, were not suddenly reduced, nor were expectations lesser. If anything, the apparatus of the state was needed to solve the massive crises of the postwar period: food, water, health, and housing (later on, also work) in halfdestroyed cities being among the most urgent problems to be addressed. Scholars working on postwar Eastern and Central European societies have argued that the postwar conditions and crises even led to a crescendo of planning and centralized state control, initially accompanied by popular approval. ${ }^{87}$ In Western Europe, technocrats, conservative and socialist politicians alike, as well as large segments of society found a consensus and also embraced the expanded, mobilized capacities of the state to solve the crises of the postwar period. ${ }^{88}$

Concerning the consensus on state planning and involvement, the Berlin and German case was typical, as were the motivations of those creating health and housing policy on location. Yet the peculiarity of the German setting should not be overlooked either. The role of National Socialism in the rise of the postwar European welfare idea is a paradoxical one. National Socialism's professed "socialism," coupled with its troubling emphasis on racial health and Volksgesundheit may have raised great expectations among a considerable portion of the German population. ${ }^{89}$ To be clear: the National Socialist regime was anything but universally egalitarian with its emphasis on racial hierarchies and resulting health and death policies. Yet its rhetoric toward those considered part of the volk was egalitarian and, as historian Norbert Frei and others have pointed out, it helped spread "sentiments of equality" across former class divisions. ${ }^{90}$ Equally important, the National Socialist compari-

86 René Girault, "Les Voies de la Reconstruction 1945-1949," in Dominique Barjot, Rémi Baudouï and Danièle Voldman, ed., Les Reconstructions en Europe (1945-1949), 33, 51.

87 For example Bradley Abrams, "The Second World War and the East European Revolution," East European Politics and Societies (Fall 2002), 623-664; Jan T. Gross, "Social consequences of war: preliminaries to the study of imposition of communist regimes in east central Europe," East European Politics and Societies, v. 3, n. 2, (Spring 1989), 198-214; Tony Judt, Postwar, 63-99; Hugh Seton-Watson, Eastern European Revolution, (London: Methuen: 1950).

88 See Barjot, et al., Les Reconstructions en Europe; Mark Mazower, Dark Continent, 298302; Tony Judt, Postwar, 63-99; Rémi Baudouï, Raoul Dautry (1880-1951). Le technocrate de la République (Paris, 1992); Philip G. Nord, France's New Deal: From the Thirties to the Postwar Era (Princeton, 2010); Herrick Chapman, "French Democracy and the Welfare State," in ed. George Reid Andrews and Herrick Chapman, The Social Construction of Democracy (New York and London, 1995).

89 Kurt Nowak, "Widerstand, Zustimmung, Hinnahme: Das Verhalten der Bevölkerung zur Euthanasie," in Norbert Frei, ed., Medizin- und Gesundheitspolitik in der NS-Zeit (München, 1991), $235 \mathrm{ff}$.

90 On the debate regarding the socialism of National Socialism, see Axel Schildt, "NSRegime, Modernisierung und Moderne: Anmerkungen zur Hochkonjunktur einer andauernden Diskussion," Tel Aviver Jahrbuch für Deutsche Geschichte, v. 23 (1994), 3-22, in response to works of Goetz Aly; Norbert Frei, "Wie modern war der Nationalsozialismus?," Geschichte und Gesell- 
sons of German public health with those of the societies living under other political systems - propagated in film, press, professional and primary education, as well as in grand-scale exhibits such as Das Sowjetparadies-would have constructed a framework which linked a society's health and living standards with the legitimacy of its government. ${ }^{91}$ This ideological framework, as the Berlin sources show, had been accepted and did not suddenly disappear in 1945. As the Allies keenly noted, Berliners in the fall of 1945 still invoked volkish health and so-called rights to life in a resentful, expectant tone. ${ }^{92}$ Likewise, German medical officials' discourses in the immediate postwar period were clearly based on nationalist premises, as historian Jessica Reinisch has convincingly demonstrated. ${ }^{93}$ Thus, among laypersons and professionals, neither terminology nor expectations had vanished in regards to public health and state responsibility. In the quest for legitimacy in the postwar quadripartite state, the Allies had to outperform the promises that Nazis had made to Germans. At the same time, the brutal, inhumane National Socialist regime and its selection based on pseudo-scientific notions of racial hygience also served as the anti-model. While the Allies had no distinct name yet for what we now refer to as the "Holocaust," and while they had not yet grasped the full extent of euthanasia programs, their increasing knowledge of these shaped their visions for the new order. From now on in Germany, there was to be no victimization or discrimination, and, ideally, welfare for all, not just for those at the top of some racist, socialdarwinist hierarchy. ${ }^{94}$ Allied policy and their preceding discussion of living standards, even for Germany, seemed determined to teach Germans the centrality of basic and universal human rights.

Finally, the wider European and global context of health and human rights favored an interventionist state. In the Berlin case, neither lingering Nazi volkish welfare ideology and expectations, nor the Allied perceived necessity to outdo NS promises alone explain the prominence of ideas regarding the importance of state involvement in public health and welfare affairs. Equally important was an increasingly publicized international human rights discourse of which Berliners would have been aware and which their claims to Allied responsibility regarding public health reflected. Already in the 1945 documents of the Potsdam Conference, and

schaft, v. 19 (1993), 367-387; Riccardo Bavaj, Die Ambivalenz der Moderne im Nationalsozialismus: Eine Bilanz der Forschung (Munich, 2003).

91 Norbert Frei, ed., Medizin- und Gesundheitspolitik in der NS-Zeit (Munich, 1991), Introduction; Michael Burleigh and Wolfgang Wippermann. The Racial State: Germany 19331945 (Cambridge, 2000); Claudia Koonz, The Nazi Conscience (Cambridge, 2005). Reichspropagandaleitung der NSDAP, Das Sowjetparadies: Ausstellung der Reichspropagandaleitung der NSDAP: Ein Bericht in Wort und Bild, (Berlin, 1943), 19, 34-35, 38-47.

92 LAB C Rep 309 A 1912 RB, Fritzner to Soviet Miliary Administration, 22 Oct.1945

93 Jessica Reinisch, “Zurück zu unserem Virchow!' - Medizinische Karrieren, Nationalhelden und Geschichtsschreibung nach 1945,” 258.

94 PRO FO 1051/803 Housing Reports I, 3 Oct. 1945. 
certainly by the time of the United Nations Declaration of Human Rights of December 1948, the advocates of universal human rights proclaimed everyone's right to "a standard of living adequate for the health and well-being of his family," and explicitly mandated states to ensure the adequacy of "housing and medical care." 95 The signatories of the 1946 Constitution of the World Health Organization had furthermore declared "the enjoyment of the highest attainable standard of health" to be "one of the fundamental rights of every human being without distinction of race, political belief, economic or social condition." ${ }^{96}$ This would presumably apply to Germans as well, despite their past. It would have also been known that the Allies in particular had been key in creating this WHO Constitution. Of all the national delegations to this conference, those of the United States, the Union of Soviet Socialist Republics, Britain, and France had been the largest and most vocal. ${ }^{97}$ And unlike the UN Declaration of Human Rights from which the Soviet Union had famously abstained, the WHO Constitution had seen no abstentions and had been unanimously adopted on 22 July $1946 .{ }^{98}$ Health in this constitution had been defined in rather general and broad terms as "a state of complete physical, mental, and social well-being and not merely the absence of disease or infirmity." What was "social well-being"? This was not exactly defined, though the absence of social well-being, according to the constitution, seemed to merit governmental "social measures" such as the provision of housing. ${ }^{100}$ Thus "governments," very explicitly, were charged with the "responsibility for the health of their peoples" and the "provision of adequate health and social measures." ${ }^{101}$ And lest those governments responsible for health provisions and policies should fail to see the wide-reaching impact, this constitution, similar to Potsdam and UN provisions, linked health with security and peace, declaring health to be "basic to the happiness, harmonious relations and security of all peoples." ${ }^{102}$ Likewise, it agreed with the United Nations Declaration of Human Rights which had provided that while

95 Art. 25 of the Universal Declaration of Human Rights, Dec. 1948: "Everyone has the right to the standard of living adequate for the health and well-being of his family, including food, clothing, housing and medical care ...."

96 United Nations World Health Organization, Official Records of the World Health Organization, No. 2: Summary Report on Proceedings, Minutes and Final Acts of the International Health Conference Held in New York from 19 June to 2 July 1946, (New York and Geneva, 1948), Preamble, 22 Jul. 1946, "Text of the Constitution of the World Health Organization," 100.

97 Ibid., 7-11.

98 Ibid., 93, "Minutes of the 17th Meeting, 22 Jul. 1946." To abide with national constitutions and procedures, most signatures had been made ad referendum, or subject to ratification by the respective delegates. The only signature marked with reservation came from Yugoslav delegate Dr. A. Stampar. Ibid., 115-118.

99 Ibid., Text of the Constitution, Preamble,100.

100 Ibid.

101 Ibid.

102 Ibid. 
the international community was to monitor abidance and, in the case of the WHO coordinate the work of individual governments and NGOs, as well as provide assistance and "promote ... the improvement of nutrition, housing, sanitation, economic or working conditions and other aspects of environmental hygiene," it was the duty of the individual nation states and their governments to ensure the right to health. ${ }^{103}$ In short, the onus to provide for health and social welfare-the basis of peace at home and peaceful, healthy relations between nations-lay upon individual states and their governments. And again, failure to ensure these most basic rights would indicate a lack of legitimacy.

The increasing Cold War divide played another important role in the connection between health care, living standards and regime legitimacy. As has been shown in the case of hospital beds, or as could be shown in the case of general living and housing conditions, the Allies continuously challenged the legitimacy of one another by pointing to their competitors' deficiencies. Initially, this was done across the board. Eventually, an East-West divide became prominent. Comparisons between living and health standards became comparisons between different regimes and types of government. Yet while pronounced inter-Allied conflict prevailed among the divisions of manpower, economics, politics or transportation from July 1945 on, within the divisions of housing and health cooperation was the norm until 1947. Though milder than in other areas, competition and smear campaigns were not entirely absent. Both in direct correspondence and via the Berlin municipal offices and even the Berlin press, sometimes in the form of friendly reminders, more often blaming the other side for being ill-guided in their policies and practices, the Allies pointed to health and housing standards in various sectors to position themselves strategically vis-à-vis other claimants for power. ${ }^{104}$ Thus the question of public health and housing appeared to be one not just concerning the health of Berliners and the Allied military on location, but one concerning the legitimacy of each of the four Allies.

Why then did they arrive at the idea of welfare and redistribution? Again, similar to the conditions after World War I, this can be explained in part by the idea of the social contract: citizens gave to the state during the war, and afterwards, they expected something in recompense. As previous historians have noted, for example Foucault in the case of Britain: "just at the moment when war was causing wholesale destruction, a society [had taken] upon itself the task of explicitly guaranteeing to its members not only the fact of life but of life lived in good health." ${ }^{105}$ The postwar convergence in welfare ideas had indeed relied heavily on mobilization and its

103 Ibid., Constitution, Art. 2a, 2i; Universal Declaration of Human Rights. Art. 22, 29.

104 Ibid., and NARA OMGUS RG 260, AG 720 Department of Public Health Berlin, December 1945 Report.

105 Michel Foucault, "Crise de la médicine ou crise de l'antimédicine," Dits et Ecrits, v. III (Paris, 1994), 40-58. 
subsequent policies during World War II. In the course of the war, states across Europe had become increasingly interventionist regarding basic welfare and health services. And, as historians and political scientists have shown in the past four decades, already during the war economic planning, nationalized services for the mobilized masses, and a rhetoric of national solidarity and common sacrifice had led to some acceptance of the re-distributionist model. ${ }^{106}$ The resistance movements across Europe had likewise embraced redistributionist policies for mere survival. ${ }^{107}$

And finally, not just for mere governability issues but also from the point of view of the general population, the idea of redistribution had gained support, given not just a history of Nazi appropriation and redistribution but also the uneven destruction and loss of resources. Moreover, now the middle class was affected as well. Welfare models are more likely to be accepted in "homogeneous countries" where "issues of mutual distrust and misuse do not arise so acutely." ${ }^{108}$ Across Europe, the war with its general mobilization, the effects of bombings, and the systematic evacuation of millions, as Mark Mazower and others have noted, had brought together "classes and communities hitherto divided or ignorant of one another." In the case of Berlin housing this meant that now some members of the middle class lived in overcrowded, unsanitary conditions, sometimes in settings that mixed classes. It was perhaps less in a spirit of class solidarity or even mutual trust than in self-interest that the middle class now also embraced redistribution. For it had turned out that not all housing in the German capital was destroyed. The city was only partially destroyed. And while in some cases Berliners lived in overly crowded conditions, with sometimes more than 10 persons to a room, there was still plenty of undestroyed dwelling space. Once the gaze had moved beyond the immediate destruction which had at first seemed total, it was evident that a good number of Berliners lived well and with ample space. It was not uncommon that only one apartment of a building was rendered inhabitable while the rest remained intact. According to a 1946 Berlin municipal statistic, 19.1 percent of all Berlin housing

106 Jytte Klausen, War and Welfare: Europe and the United States, 1945 to the Present (New York, 1998), 2-13; Gordon Wright, The Ordeal of Total War 1939-1945 (Prospect Heights, 1997), 234-267.

107 Ibid.; Bradley Abrams, "The Second World War and the East European Revolution," East European Politics and Societies, (Fall 2002), 623-664

108 Tony Judt, "What Is Living and What Is Dead In Social Democracy?," New York Review of Books, v. 56, n. 20, (Dec. 17, 2009).

109 Mark Mazower, Dark Continent, 185. 
Image 3. Partial rather than total destruction favored a redistributionist approach.

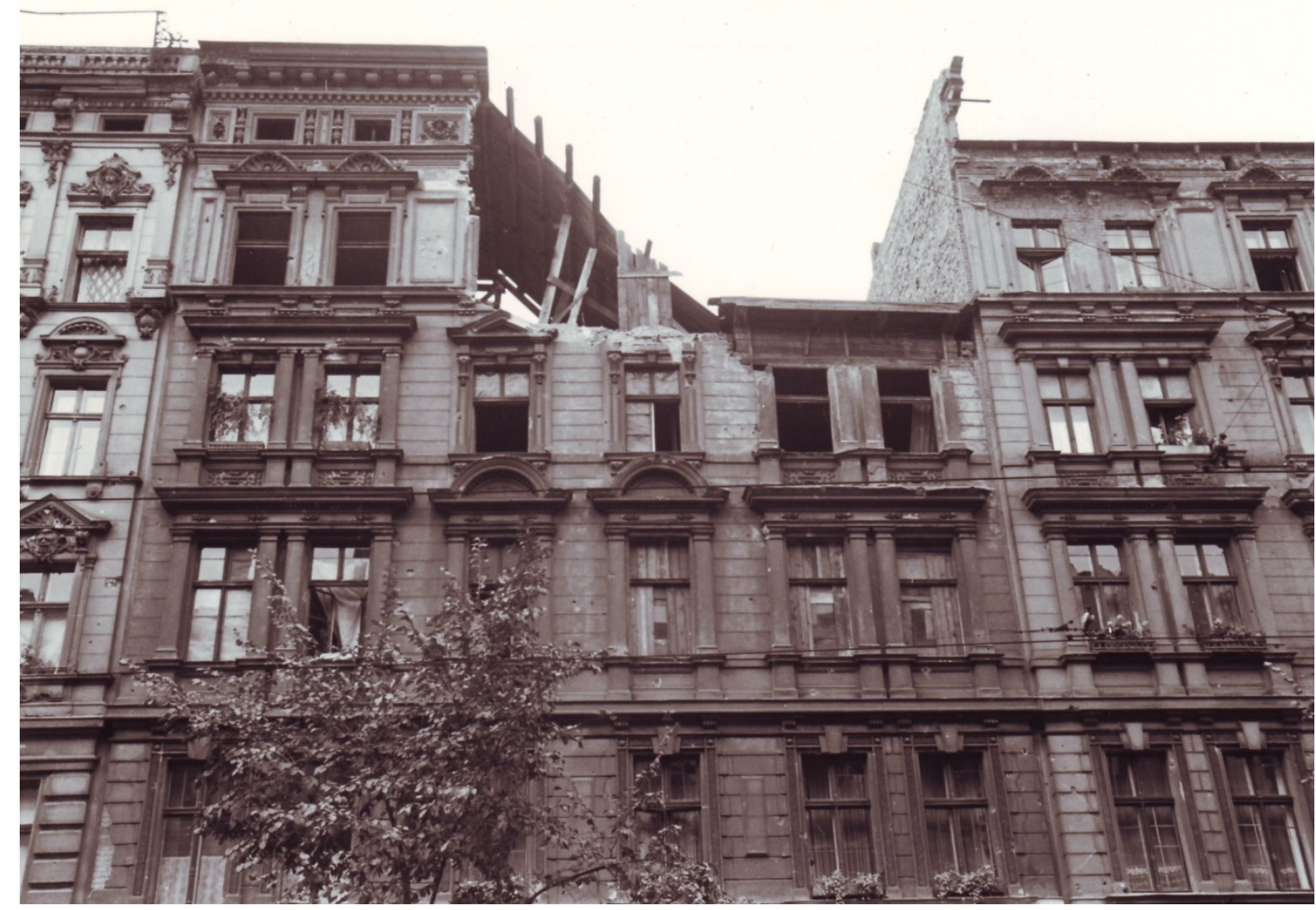

Courtesy of Landesarchiv Berlin/Otto Hagemann, 1947.

was destroyed beyond repair. ${ }^{110}$ This meant that there was a critical mass of Berliners affected and calling for redistribution. But it also meant that there were still enough resources to be distributed.

Not only Berliners, but also Soviet, American, British and French housing and health officials realized that, given the lack of monetary resources, redistribution would be the route to take. ${ }^{111}$ Reconstruction was not an option in 1945 or 1946. Allied policy-writers, furthermore, had to take into account that their native countries also suffered a scarcity of funds and resources and that any resources going to Germany rather than to their own country would be met with scrutiny. ${ }^{112}$ At the same time, charged with governing Berlin, the Allies were interested in governabil-

110 "Gebäudezustand nach Beendigung der Kampfhandlungen" in Mitteillungen des Hauptvermessungsamtes der Stadt Berlin, 1946.

111 PRO FO 1051/803, Housing Reports I, “Housing in Berlin,” letter Brigadier Ryan to A. E. Joll, 30 Aug. 1945, pp. 1-2; PRO FO 1051/803, Housing Reports I, letter Major H. Nuttall to Lt. Col. J. D. Watt, 6 Sep. 1945.

112 CArch, Groupe Française de Conseil de Contrôle [1945-1948], Caisse No. 3272, Carton No. P32. Correspondence GFCC Division Travail - Commandement en Chef Français en Allemagne - Com[m]ité de Logement, Letter C. Dechamp to Colonel Blachere, Berlin-Frohnau, 15 Sep. 1945; NARA RG 260 OMGUS 1945-46 AG 720, Jan. 1946 Report. 
ity and wanted Berliners content. Already in the fall of 1945, they had contemplated state-directed reallocation of resources, noting "there should be a complete survey made by sector and redistribution of population before [the] end [of] October for a) overcrowding, pure and simple, b) damaged conditions, c) unhealthy conditions." ${ }^{\prime 13}$ While such redistribution proved a complicated affair, the ideas soon took hold in laws as well. As a result, for example, taxes for hospitals and building reconstruction were levied, and the joint Allied housing legislation of 1946 already included the idea of redistribution. The law justified this policy by noting that rights for living standards should be universal and available to all. ${ }^{114}$ This basic premise of redistribution, not mere reconstruction, lay at the foundation of postwar Germany and would be continued after 1949 in both German states. ${ }^{115}$

\section{Conclusion}

As the European health and welfare models are being re-evaluated in our own time, it may be good to remind ourselves of the circumstances under which they evolved. The physical context, the debris coupled with a massive population flux, as well as an acute housing and health crisis, played an important role. The evidence of the Berlin case furthermore points to a physical setting in which Allies and local populations were aware of the commonality of the context beyond the confines of Berlin. In Berlin, they worked with each other, exchanging ideas and letters, visiting each other, founding think tanks on health and housing problems as they considered a problem shared by all. They likewise were part of an engaged global human rights discourse which came as a response to the racist, exclusivist policies of the National Socialists and which set out to make health rights universal. This is the positive view.

However, housing and health considerations and policies were not primarily motivated by a common concern about the well-being of the populations. Allies and local population alike heavily relied on a war-time tradition of state involvement and planning in regard to public health and housing. In other words, they continued along interventionist structures which had roots in earlier welfare policies, not least those established during World War II. Despite their bleak outlook on the shambles around them, Europeans had expectations vis-à-vis their governments. Finally, as this paper has argued, the postwar interventionist consensus was

113 PRO FO 1051/803. Major Nuttall Report, "Notes on Visits to Various Premises in Berlin on 10. Sep. 1945,” pp. 1-2.

114 PRO FO1051/720, Housing Law 18, Allied Kommandatura Decree, March 1946.

115 See for example Paul Betts, "Building Socialism at Home: The Case of East German Interiors," in Socialist Modern: East German Everyday Culture and Politics, eds. Katherine Pence and Paul Betts (Michigan, 2008), 96-132. 
driven by Allied and German administrators' search for political order, security and legitimacy at a time in which these were deemed painfully absent.

The late Historian Tony Judt has reminded us to pay attention to the significance of the early postwar period across Europe as one in which the groundwork for the latter half of the twentieth century was laid. ${ }^{116}$ And he has reminded us of the conditions at the time: in these first postwar years, most Europeans did not expect a bright future. ${ }^{117}$ The world to them was threatening, unclear and disordered. All across Europe, cities and entire societies were in shambles. ${ }^{118}$ Almost all European countries shared a severe housing crisis. And in all settings, not least in the case of Berlin, war and catastrophe as well as the immanent danger of epidemics and unrest gave rise to discussions about the ideal redistribution of space and power, about a new order, and about the prevention of future calamities, not least of all aggressive nationalist politics and the rise of yet another Hitler.

Clara Oberle is Assistant Professor at the Department of History, University of San Diego.

116 Tony Judt, Postwar: A History of Europe Since 1945.

117 Ibid., 3, 13.

118 Ibid., 13-40. 


\section{References}

Abrams, Bradley, "The Second World War and the East European Revolution," East European Politics and Societies (Fall 2002).

Abrosimov, Pavel V. (ed.), Stroitelstvo i rekonstruktsiia gorodov, 1945-1957l Construction et reconstruction des villes, 1945-1957 (Moscow, 1958).

Ahrens, Ralf, "Planwirtschaft, Prävention und Effizienz: Zur Wirtschaftsgeschichte des Gesundheitswesens in der Sowjetischen Besatzungszone und der frühen DDR," in Udo Schagen and Sabine Schleiermacher, (eds.), Sozialmedizin, Sozialhygiene, Public Health: Konzepte und Visionen zum Verhältnis von Medizin und Gesellschaft in historischer Perspektive, Series Berichte und Dokumente zur Zeitgeschichte 5 (Berlin, 2002), 42.

Bavaj, Riccardo, Die Ambivalenz der Moderne im Nationalsozialismus: Eine Bilanz der Forschung (Munich, 2003).

Baudouï, Rémi, Raoul Dautry (1880-1951). Le technocrate de la République (Paris: 1992).

Bertheim, Sidney, "Housing in France," Land Economics, v. 24, n. 1 (Feb. 1948).

Bessel, Richard. "Hatred after War: Emotion and the Postwar History of East Germany," History and Memory, 17(1), (2005).

Betts, Paul, "Building Socialism at Home: The Case of East German Interiors," in Socialist Modern: East German Everyday Culture and Politics, in Katherine Pence and Paul Betts (eds.), (Michigan, 2008), 96-132.

Boucher, Frédérique and Danièle Pauly, L'Architecture de la Reconstruction en France 1945-1953 (Paris, 1982).

Boucher, Frédérique, "Arbiter vaille que vaille, se loger coûte que coûte," in Danièle Voldman, (ed.), Images, Discours et Enjeux de la Reconstruction des Villes Françaises après 1945, Cahiers de l'Institut d'histoire du temps présent, n. 5 (1987), 157.

Brakman, Steven, Harry Garretsen, and Mark Schramm, "The strategic bombing of German cities during World War II and its impact on city growth," Journal of Economic Geography 4 (2004), 201-218

Burleigh, Michael, and Wolfgang Wippermann, The Racial State: Germany 19331945 (Cambridge, 2000).

Chapman, Herrick, "French Democracy and the Welfare State," in ed. George Reid Andrews and Herrick Chapman, The Social Construction of Democracy (New York and London, 1995).

Commissions Départmentales de la Reconstruction, Bulletin des commissions départementales de la reconstruction 4 (1946), 6-8.

Dinter, Andreas. Berlin in Trümmern. Ernährungslage und medizinische Versorgung der Bevölkerung Berlins nach dem II. Weltkrieg and Seuchenalarm in Berlin. 
Seuchengeschehen und Seuchenbekämpfung in Berlin nach dem II. Weltkrieg, Geschichte(n) der Medizin Series, 1-2. (Berlin, 1999).

Durie, William, Friedrich Jeschonnek, Dieter Riedel, et al., Alliierte in Berlin: 19451994: Ein Handbuch zur Geschichte der militärischen Präsenz der Westmächte (Berlin, 2002).

Foitzik, Jan, (ed.), Inventar der Befehle des Obersten Chefs der Sowjetischen Militäradministration in Deutschland (SMAD) 1945-1949, Series of Institut für Zeitgeschichte (Munich, 1995).

Förster, Alice and Birgit Beck, "Posttraumatic Stress Disorder and World War II," in Richard Bessel and Dirk Schumann, (eds.), Life After Death: Approaches to a Cultural and Social History of Europe During the 1940s and 1950s (Cambridge, 2003), 28-30.

Foucault, Michel, "Crise de la médicine ou crise de l'antimédicine," Dits et Ecrits, v. III (Paris, 1994), 40-58.

Frei, Norbert, "Wie modern war der Nationalsozialismus?," Geschichte und Gesellschaft, 19 (1993), 367-387.

Frei, Norbert, (ed.), Introduction, Medizin- und Gesundheitspolitik in der NS-Zeit (Munich, 1991).

Frisby, David, "The City Rationalized," in Cityscapes of Modernity: Critical Explorations (Cambridge, 2001), 270-302.

Girault, René, "Les Voies de la Reconstruction 1945-1949," in Dominique Barjot, Rémi Baudouï and Danièle Voldman, (eds.), Les Reconstructions en Europe (1945-1949) (Brussels, 1997).

Goedde, Petra, GIs and Germans: Culture, Gender and Foreign Relations (New Haven, 2003).

Glowny Urzad Staystyczny Polskiej Rzeczypospolitej Ludowej, (ed.), Tablice Statistyczne 1953-1954 (Warsaw, 1956), 381-387.

Gross, Jan T., "Social Consequences of War: Preliminaries to the Study of Imposition of Communist Regimes in East Central Europe," East European Politics and Societies, 3(2), (Spring 1989).

Grossman, Atina, "A Question of Silence: The Rape of German Women by Occupation Soldiers," October, 72, (Spring 1995).

Grossman, Atina, Jews, Germans, and Allies: Close Encounters in Occupied Germany (Princeton, 2007).

Hagemann, Karen and Stefanie Schuller-Springorum, Home/Front: The Military, War, and Gender in Twentieth-Century Germany (Oxford/New York, 2002).

Hauptvermessungsamt der Stadt Berlin, "Gebäudezustand nach Beendigung der Kampfhandlungen," Mitteillungen des Hauptvermessungsamtes der Stadt Berlin, 1946.

Huyssen, Andreas et al., "Further Thoughts on Helke Sander's Project" October, 72 (Spring 1995). 
Judt, Tony, Postwar: A History of Europe Since 1945 (New York, 2005).

Judt, Tony, "What Is Living and What Is Dead In Social Democracy?," New York Review of Books, 56(20), (Dec. 17, 2009).

Kästner, F., Statistisches Jahrbuch Deutscher Gemeinden 37 (1949), 361-391.

Kasza, Gregory, "War and Welfare Policy in Japan," Journal of Asian Studies, 61(2) (May, 2002), 417.

Klausen, Jytte, War and Welfare: Europe and the United States, 1945 to the Present (New York, 1998), 2-13.

Koehler, Fred K., "Europe's Homeless Millions," Headline Series 54, (Nov.-Dec. 1945).

Koonz, Claudia, The Nazi Conscience (Cambridge, 2005).

La Berge, Ann, Mission and Method: The Early Nineteenth-Century French Public Health Movement (Cambridge, 1992), 16.

Labisch, Alfons and Florian Tennstedt, "Gesundheitsamt oder Amt für Volksgesundheit? Zur Entwicklung des öffentlichen Gesundheitsdienstes seit 1933" in (ed.) Norbert Frei, Medizin und Gesundheitspolitik in der NS-Zeit (Munich, 1991).

Landmann, Herbert, "In Berlin begann der Kampf gegen die Tuberkulose," Berlinische Monatsschrift, 12 (1998), 12-13, 17.

Lebow, Katherine. Nowa Huta, 1949-1957: Stalinism and the Transformation of Everyday Life in Poland's "First Sociality City." (New York, 2002), 25.

Mazower, "Displacement and Social Crisis," in Dark Continent: Europe's Twentieth Century (New York, 1998), 214 ff.

Naimark, Norman. Russians in Germany: A History of the Soviet Zone of Occupation, 1945-1949 (Cambridge, 1995).

Nikolow, Sybilla, "Statistische Bilder der Bevölkerung in den großen Hygienausstellungen als Wissensobjekte," in Rainer Mackensen and Jürgen Reulecke, (ed.), Das Konstrukt "Bevölkerung" vor, im und nach dem "Dritten Reich" (Wiesbaden, 2005).

Nord, Philip G., France's New Deal: From the Thirties to the Postwar Era (Princeton, 2010).

Nowak, Kurt, "Widerstand, Zustimmung, Hinnahme: Das Verhalten der Bevölkerung zur Euthanasie," in Norbert Frei, (ed.), Medizin- und Gesundheitspolitik in der NS-Zeit (Munich, 1991).

Osborne, Thomas, "Of Health and Statecraft," in Alan Petersen and Robin Bunton, (eds.), Foucault, Health and Medicine (London, 1997), 173-188.

Pettenkofer, Max von, Über den Luftwechsel in Wohngebäuden (Munich, 1858).

Podewin, Norbert, (ed.), Ausgangspunkt Chaos: Berlin im Mai und Juni 1945: 100 Dokumente vom Leben rund um den Schlesischen Bahnhof (Berlin, 1995), 16.

Rastelli, Achille, "I bombardimenti aeri nella seconda guerra mondiale Milano e provincia," Italia Contemoranea, v. 195 (June 1994), 309-342. 
Reichspropagandaleitung der NSDAP, Das Sowjetparadies: Ausstellung der Reichspropagandaleitung der NSDAP: Ein Bericht in Wort und Bild (Berlin, 1943).

Reinisch, Jessica, “'Zurück zu unserem Virchow!' - Medizinische Karrieren, Nationalhelden und Geschichtsschreibung nach 1945," in Axel C. Hüntelmann, Johannes Vossen and Herwig Czech, (eds.), Gesundheit und Staat: Studien zur Geschichte der Gesundheitsämter in Deutschland, 1870-1950 (Husum, 2006).

Rudolph, Nicole, At Home in Postwar France: The Design and Construction of Domestic Space, 1945-1975 (New York, 2005), 20.

Rürup, Reinhard, (ed.), Berlin 1945: Eine Dokumentation (Berlin, 1995), 124.

Sachße, Christoph, and Florian Tennstedt, Der Wohlfahrtsstaat im Nationalsozialismus (Stuttgart/Berlin, 1992).

Schagen, Udo and Sabine Schleiermacher, "Gesundheitswesen und Sicherung bei Krankheit," in Bundesministerium für Arbeit und Sozialordnung/ Bundesarchiv, (eds.), Geschichte der Sozialpolitik in Deutschland, v 2: Die Zeit der Besatzungszonen 1945-1949 (Baden Baden, 2002).

Schildt, Axel, "NS-Regime, Modernisierung und Moderne: Anmerkungen zur Hochkonjunktur einer andauernden Diskussion," Tel Aviver Jahrbuch für Deutsche Geschichte, 23 (1994).

Schmiedebach, Heinz-Peter, "Gesundheit und Prävention in Abhängigkeit vom Gesellschaftsbegriff im 19. Jahrhundert," in Sigrid Stöckl et al., Prävention im 20. Jahrhundert: Historische Grundlagen und aktuelle Entwicklungen in Deutschland (Weinheim, 2002), 27.

Seton-Watson, Hugh. Eastern European Revolution (London, 1950).

Simone, Cesare de, Venti angeli sopra Roma: I bombardimenti aeri sulla Città Eterna 19 luglio e 13 agosto 1943 (Milan, 1993).

Ther, Philip, Deutsche und polnische Vertriebene: Gesellschaft und Vertriebenenpolitik in der SBZ/DDR und in Polen, 1945-1956 (Göttingen, 1998).

Thum, Gregor, Die Fremde Stadt: Breslau 1945 (Berlin, 2003).

Universities Committee on Post-War International Problems, (ed.), Ralf Barton Perry, Final Report of the Work of the Committee 1942-1945, Section V. (Boston, 1945), 3.

United Nations, Chronicle of the World Health Organization, 1(1) (1947), 8.

United Nations World Health Organization, Preamble, 22 Jul. 1946, "Text of the Constitution of the World Health Organization," Official Records of the World Health Organization, No. 2: Summary Report on Proceedings, Minutes and Final Acts of the International Health Conference Held in New York from 19 June to 2 July 1946 (New York and Geneva, 1948).

Virchow, Rudolf, "Die öffentliche Gesundheitspflege," Die Medizinische Reform n. 1 (1848), 22. 
Voldman, Danièle, La reconstruction des villes françaises de 1940 à 1954. Histoire d'une politique (Paris, 1997).

Wendt, Paul F., "Post World-War II Housing Policies in Italy," Land Economics, 38(2), (May 1962), 113-133.

Wolgast, Eike, Die Wahrnehmung des Dritten Reiches in der unmittelbaren Nachkriegszeit 1945/46 (Heidelberg, 2001).

Wright, Gordon, The Ordeal of Total War 1939-1945 (Prospect Heights, 1997). 